\title{
PERBEDAAN TINGKAT KESEGARAN JASMANI ANTARA SISWA SMK TARUNA 2 PADANG DENGAN SMA PERTIWI 1 PADANG
}

\author{
Septri $^{2)}$
}

\begin{abstract}
ABSTRAK
Penelitian ini bertujuan untuk mengetahui perbedaan tingkat kesegaran jasmani siswa SMK Taruna 2 Padang dengan SMA Pertiwi 1 Padang Jenis penelitian ini adalah expost facto. Populasi dalam penelitian ini adalah seluruh siswa-siswi pada SMK Taruna 2 Padang dan SMA Pertiwi 1 Padang kecuali siswa kelas XII karena persiapan menghadapi ujian akhir nasional. Populasi dalam penelitian ini 55 orang siswa SMK Taruna Padang dan 118 orang siswa SMA Pertiwi Padang, dengan jumlah keseluruhan 173 orang. Pengambilan sampel menggunakan teknik stratified porputional ramdom sampling sehingga sampel penelitian berjumlah 28 orang. Teknik analisis data yang menggunakan analisis Uji t.Dari analisis data menunjukan bahwa terdapat perbedaan tingkat kesegaran jasmani antara siswa SMK Taruna 2 Padang dengan siswa SMA Pertiwi 1 Padang yang ditunjukan dengan skor $X_{1}=33,98>X_{2}=27,27$ dan dengan menggunakan $\mathrm{t}$ test didapatkan $\mathrm{t}_{\text {hitung }}=-4,09>\mathrm{t}_{\text {tabel }}$ 1,76. Jadi dapat disimpulkan kesegaran jasmani siswa SMK Taruna 2 Padang lebih baik dari siswa SMA Pertiwi 1 Padang. Hal ini juga ditujukkan dengan tingkat signifikan sebesar 0,001<0,05, yang berarti menunjukkan hasil bahwa terdapat perbedaan yang signifikan antara tingkat kesegaran jasmani antara siswa SMK Taruna 2 Padang dengan tingkat kesegaran jasmani siswa SMA Pertiwi 1 Padang. Dengan demikian bahwa terdapat perbedaan yang signifikan antara tingkat kesegaran jasmani siswa SMK Taruna 2 Padang dengan siswa SMA Pertiwi 1 Padang.
\end{abstract}

Kata Kunci : Kesegaran Jasmani

\begin{abstract}
This study aims to determine differences in physical fitness level of students SMK Taruna 2 Padang with SMA Pertiwi 1 Padang This research type is expos facto. The population in this study is all students in SMK Taruna 2 Padang and SMA Pertiwi 1 Padang except the class XII students because of preparation for the final national examination. The population in this study were 55 students of SMK Taruna Padang and 118 students of SMA Pertiwi Padang, with a total of 173 people. Sampling using stratified technique porputional ramdom sampling so that the research sample amounted to 28 people. Technique of data analysis using $\mathrm{t}$ test analysis. From data analysis show that there is difference of physical fitness level between student of SMK Taruna 2 Padang with student of SMA Pertiwi 1 Padang shown with score $\mathrm{X} 1=33,98>\mathrm{X} 2=27,27$ and by using $\mathrm{t}$ test obtained tcount $=-4.09>$ ttabel 1.76. So it can be concluded the physical fitness of students SMK Taruna 2 Padang better than students of SMA Pertiwi 1 Padang. This is also

${ }^{2)}$ Septri. Saat ini Dosen Jurusan Kesehatan dan Rekreasi Fakultas Ilmu Keolahragaan Universitas Negeri Padang
\end{abstract}


indicated by a significant level of $0.001<0.05$, which means that there is a significant difference between the level of physical fitness between students SMK Taruna 2 Padang with physical fitness level of students of SMA Pertiwi 1 Padang. Thus, there is a significant difference between physical fitness level of students of SMK Taruna 2 Padang with high school students Pertiwi 1 Padang.

Keywords: Physical Fitness

\section{PENDAHULUAN}

Dalam mewujudkan masyarakat yang adil dan makmur pemerintah Indonesian melakukan pembangunan di segala bidang, termasuk dintaranya pembangunan dibidang pendidikan. Pembangunan dibidang pendidikan bertujuan untuk menciptakan Sumber Daya Manusia (SDM) yang berkualitas, yaitu sumber daya yang berilmu pengetahuan, memiliki keterampilan, sehat jasmani dan rohani serta memiliki sikap dan perilaku yang terpuji. Hal ini sesuai dengan Undangundang Sistim Pendidikan Nasional pada Bab II pasal 3 Undang-undang RI No. 20 Tahun 2003 yang berbunyi:

"Pendidikan nasional berfungsi mengembangkan kemampuan dan membentuk watak serta peradaban bangsa yang bermatabat dalam rangka mencerdaskan kehidupan bangsa, bertujuan untuk berkembangnya potensi peserta didik agar menjadi manusia yang beriman dan bertaqwa kepada Tuhan Yang Maha Esa, berakhlak mulia, sehat berilmu, cakap kreatif, mandiri dan menjadi warga negara yang demokratis serta bertanggung jawab."

Untuk mencapai tujuan pendidikan tersebut maka di susun kurikulum untuk semua bidang studi pada setiap jenjang pendidikan mulai dari SD sampai dengan SMA, setiap bidang studi yang diajarkan mempunyai tujuan masingmasing tapi tetap mengacu kepada tujuan pendidikan nasional.

Berdasarkan uraian di atas, mengandung harapan bahwa pendidikan di Indonesia berfungsi untuk mengembangkan kepribadian peserta didik agar mampu menyerap pelajaran yang mereka dapat di sekolah baik dalam jam pelajaran biasa maupun dalam aktivitas pengembangan diri (ekstrakurikuler) di luar jam pelajaran. Melalui proses pendidikan anak didik diharapkan mampu

${ }^{2)}$ Septri. Saat ini Dosen Jurusan Kesehatan dan Rekreasi Fakultas Ilmu Keolahragaan Universitas Negeri Padang 
mengembangkan potensi yang ada di dalam dirinya demi memenuhi kebutuhan hidupnya, masyarakat dan negara sekarang dan di masa yang akan datang.

Pembelajaran pendidikan jasmani di tingkat pendidikan menengah atas dalam Mulyasa (2006:26) KTSP antara lain difokuskan pada, "Pengembangan aspek kebugaran atau kesegaran jasmani dan keterampilan gerak". Sesuai dengan kurikulum KTSP diatas, mata pelajaran Pendidikan jasmani olahraga dan kesehatan yang diajarkan di sekolah, diberikan sesuai dengan tujuan kurikulum yaitu:

“(1) mengembangkan keterampilan pengelolaan diri dalam upaya pengembangan dan pemeliharaan kebugaran jasmani serta pola hidup sehat melalui berbagai aktivitas dan olahraga yang terpilih; (2) meningkatkan pertumbuhan dan pengembangan psikis yang lebih baik; (3) meningkatkan kemampuan gerak dasar; (4) meletakkan kemampuan dan keterampilan gerak dasar; (5) meletakakan landasan karakter moral yang kuat melalui intelegensi nilai-nilai yang terkandung didalam pendidikan jasmani olahraga dan kesehatan; (6) mengembangkan keterampilan untuk menjaga keselamatan diri sendiri, orang lain dan lingkungan; dan (7) memahami konsep aktivitas jasmani dan olahraga dilingkungan yang bersih sebagai informasi untuk mencapai pertumbuhan fisik sempurna, pola hidup sehat dan kebugaran, keterampilan serta memiliki sikap yang positif"'.

Sesuai dengan tujuan KTSP di atas diharapkan pembelajaran Penjasorkes dapat mencapai tujuan pembelajaran yang optimal dan meningkatkan kesegaran jasmani dan rohani. SMK (Sekolah Menengah Kejuruan) Taruna 2 Padang adalah salah satu lembaga pendidikan formal sederajat dengan Sekolah Menengah Atas.. Siswa-siswi SMK Taruna Padang sebagian besar berasal dari luar kota Padang bahkan ada yang berasal dari luar Sumbar. Di sekolah ini telah diterapkan disiplin semi militer dimana siswa dituntut memiliki disiplin yang tinggi, dalam keseharian proses pendidikan apabila anak melakukan kesalahan atau pelanggaran terhadap peraturan yang ada, siswa diberi sangsi melakukan aktivitas fisik seperti push-up, skuat-jump dan lari. Di sekolah SMK Taruna 2 Padang telah diterapkan ekstrakurikuler khususnya keterampilan olahraga beladiri yang dilakukan dua

${ }^{2)}$ Septri. Saat ini Dosen Jurusan Kesehatan dan Rekreasi Fakultas Ilmu Keolahragaan Universitas Negeri Padang 
kali dalam seminggu diluar jam pelajaran Penjasorkes. Ekstrakurikuler yang diterapkan di SMK Taruna 2 Padang khususnya karate yang wajib diikuti oleh seluruh siswa dan juga dicantumkan dalam nilai rapor. Sementara kurikulum yang digunakan sama dengan SMK lainnya terutama untuk Penjasorkes.

Sedangkan SMA (Sekolah Menengah Atas) Pertiwi 1 Padang adalah salah satu lembaga pendidikan formal sama dengan SMA lainnya yang berada di kota Padang. Pada SMA Pertiwi 1 Padang latar belakang siswanya sebagian besar berasal dari kota Padang sekitarnya. Kalau dilihat dari aktivitas yang dilakukan siswa-siswi SMA Pertiwi 1 Padang untuk kegiatan ekstrakurikuler di sekolah ini juga telah berjalan olahraga beladiri khususnya Tarung Derajat, tidak semua siswa ikut tetapi yang berminat saja dan tidak dicantumkan dalam nilai rapor, walaupun demikian belum dapat menentukan secara pasti murid sekolah mana yang lebih baik tingkat kesegaran jasmaninya. Sementara kurikulum yang digunakan sama dengan SMA lainnya terutama untuk bidang studi Penjasorkes.

Faktor-faktor penyebab terjadinya perbedaaan tingkat kesegaran jasmani siswa SMK Taruna 2 Padang dan SMA Pertiwi 1 Padang diantaranya dipengaruhi oleh faktor: gizi, kondisi lingkungan, keadaan ekonomi, aktivitas fisik yang dilakukan, kesehatan lingkungan, kebiasaan dan banyak lagi faktor yang dapat mempengaruhi tingkat kesegaran jasmani siswa.

\section{Hakekat Kesegaran Jasmani}

Kesegaran jasmani yang merupakan gambaran tentang kondisi fisik tubuh seseorang sehingga diharapkan tubuh akan dapat beradaptasi dengan lingkungan sekelilingnya dalam melakukan aktivitas sehari-hari. Hairy (1989:17) mengemukakan kesegaran jasmani adalah "kemampuan untuk melaksanakan tugas sehari-sehari dengan giat dan dengan penuh kewaspadaan, tanpa mengalami kelelahan yang berarti dalam menghadapi hal-hal yang darurat yang tidak terduga sebelumnya".

Sebagaimana dikemukakan Sodoso (2000:34) mengemukakan bahwa : "kesegaran jasmani lebih menitik beratkan kepada PHISICAL FITNESS yaitu kemampuan tubuh untuk menyesuaikan fungsi. Alat-alat dalam fisiologis terhadap

${ }^{2)}$ Septri. Saat ini Dosen Jurusan Kesehatan dan Rekreasi Fakultas Ilmu Keolahragaan Universitas Negeri Padang 
keadaan lingkungan ketinggian, kelembaban, suhu dan sebagainya”. Selain itu O Sullivan (1987:86) juga mengemukakan bahwa :

"Kesegaran jasmani adalah suatu kemampuan untuk melakukan kegiatan sehari-hari yang normal dengan giat dan penuh dengan kesiap-siagaan tanpa mengalami kelelahan yang berarti dan masih mempunyai cadangan energi untuk menikmati kegiatan waktu senggang serta kejadian darurat yang datang tiba-tiba".

Dari pendapat di atas, maka semakin jelaslah bahwa kesegaran jasmani merupakan suatu kondisi fisik tubuh dalam mempertahankan atau dengan lingkungan, sehingga aktivitas yang dilakukan sehari-hari tidak mengalami hambatan karena tubuh telah mempunyai kondisi yang baik dalam menghadapi hambatan-hambatan tersebut makanya seseorang mampu melawan pengaruhpengaruh luar dan tidak mengurangi efisiensi kondisi badan.

Oleh karena itu kesegaran jasmani merupakan suatu yang dipengaruhi oleh aktivitas fisik dan latihan olahraga sehari-hari, semakin banyak aktivitas fisik dalam latihan olahraga yang dilakukan seseorang, maka semakin baik pula tingkat kesegaran jasmaninya. Melakukan aktivitas fisik dan latihan olahraga akan meningkatkan kemampuan tubuh dalam mengkonsumsi oksigen secara maksimal, secara otomatis akan berpengaruh terhadap kesegaran jasmani.

Sebagaimana yang dikemukakan oleh Sumoharjono (1984) bahwa: "untuk mendapatkan kesegaran jasmani yang baik, sebaiknya kita menjalankan olahraga yang teratur". Dan ini diperkkuat pula oleh Siregar (1994) yang mengatakan: "untuk mendapatkan kesegaran jasmani atau kapasitas aerobik perlu dilakukan latihan-latihan olahraga yang teratur dengan tujuan meningkatkan sistem transpor oksigen".

Sekarang dapat disimpulkan, bahwa kesegaran jasmani itu adalah aspekaspek kemampuan fisik yang dapat menunjang kesuksesan siswa dalam melakukan berbagai aktivitas dalam kehidupan sehari-hari tanpa mengakibatkan kelelahan yang berarti. Kegiatan itu dapat berupa pekerjaan sehari-hari dan untuk keperluan mendadak atau pekerjaan itu dilakukan dalam waktu senggang, karena semakin tinggi tingkat kesegaran jasmani yang dimiliki seseorang, maka semakin

${ }^{2)}$ Septri. Saat ini Dosen Jurusan Kesehatan dan Rekreasi Fakultas Ilmu Keolahragaan Universitas Negeri Padang 
besar pula kemungkinannya untuk dapat menyelesaikan suatu pekerjaan dan menikmati kehidupan.

Sebenarnya kualitas fisik sangat erat hubungannya dengan kualitas hidup seseorang, karena banyak faktor yang mempengaruhi diantaranya, usia jenis kelamin, dan lain-lain sehingga faktor tersebut akan jelas membedakan tingkat kesegaran jasmani seseorang itu. Sebagaimana yang dikemukakan Gusril (2004:119) bahwa kesegaran jasmani akan berbeda dan tergantung pada : "a) jenis pekerjaan; b) keadaan kesehatan; c) jenis kelamin; d) umur; e) tingkat terlatihnya seseorang dan; f) status gizi”.

Dari uraian di atas, dapat diambil kesimpulan yaitu untuk meningkatkan kesegaran jasmani perlu dilakukan latihan olahraga yang teratur dan melaksanakan pekerjaan sehari-hari yang berguna untuk meningkatkan daya fikir.

\section{Ciri-ciri Kesegaran jasmani}

Sedangkan ciri-ciri orang yang mempunyai kesegaran jasmani sebagaimana pendapat Djamil dalam Gusril (2004:123) yaitu sebagai berikut:

“a) Resisten terhadap penyakit; b) memiliki daya tahan jantung (Cardio Vasculer), paru-paru, peredaran darah, dan pernafasan (Respirasi); c) memiliki daya tahan otot umum; d) mempunyai daya tahan otot lokal; e) memiliki daya ledak otot; f) memiliki kelentukan; g) memiliki kecepatan; h) memiliki kekuatan dan; i) memiliki koordinasi (Coordination) dan ketepatan".

Kalau dilihat pula tentang ciri-ciri dari tingkat kesegaran jasmani yang berada di bawah standar menurut Cooper dan Brown (1990) adalah sebagai berikut:

“a) Menguap dimeja makan; b) perasaan malas dan mengantuk sepanjang hari; c) cederung bertingkah marah; d) merasa lelah dengan kerja fisik yang minimal; e) terlalu capek untuk melakukan aktivitas senggang; f) penggugup dan mudah terkejut; h) sukar rileks; i) mudah lemas dan sedih dan; j) mudah tersinggung".

Bedasarkan pendapat di atas, jelas bahwa kesegaran jasmani sangat berpengaruh terhadap kualitas hidup seseorang. Orang yang memiliki kesegaran

\footnotetext{
${ }^{2)}$ Septri. Saat ini Dosen Jurusan Kesehatan dan Rekreasi Fakultas Ilmu Keolahragaan Universitas Negeri Padang
} 
jasmani yang bagus akan mempunyai kualitas hidup yang lebih bagus pula, begitu juga sebaliknya. Selain itu, dapat dikatakan orang yang memiliki kesegaran jasmani yang buruk seperti ciri-ciri yang dikemukakan diatas tentu sulit mencapai kesuksesan dalam hidup dan memiliki kualitas hidup yang buruk pula.

\section{Faktor-faktor yang Menentukan Kesegaran Jasmani}

Kesegaran jasmani merupakan salah satu faktor penting untuk menunjang prestasi siswa, dengan mempunyai kesegaran jasmani yang tinggi mereka dapat belajar dengan baik dan sungguh-sungguh dibanding dengan mereka yang tidak mempunyai kondisi yang baik. Faktor yang mempengaruhi kesegaran jasmani akan membatasi jumlah energi yang dapat dilepaskan secara aerobik adalah:

1) Kemampuan kimia dalam rangkaian sel dalam otot untuk menggunakan oksigen dalam menggunakan energi.

2) Kemampuan yang dikombinasikan dengan sistem yang berkenaan dengan paru-paru dan kardiovaskuler untuk mengangkut oksigen ke dalam sistem jaringan otot. (Brainmac, http.//Wikepedia. Kesegaran VO 2 Max).

Sedangkan fungsi fisiologis yang terlihat dalam kapasitas konsumsi oksigen maksimal adalah:

1) Jantung, paru dan pembuluh darah harus berfungsi dengan baik sehingga oksigen yang dihisap dapat masuk keparu-paru, selanjutnya sampai kedarah.

2) Proses penyampaian oksigen kejaringan-jaringan

Sedangkan menurut Lamb D.R dalam Kosbian (2004) fungsi fisiologi yang terlihat dalam faktor kapasitas konsumsi oksigen maxsimal adalah:

“1) Jantung, paru dan pembuluh darah harus berfungsi dengan baik sehingga oksigen yang dihirup dapat masuk ke paru, selanjutnya masuk ke darah.

2.) Proses penyampaian oksigen kejaringan-jaringan oleh sel-sel darah merah harus normal, yaitu fungsi jantung harus normal, volume darah harus normal, jumlah sel-sel darah merah harus normal dan konsisten hemoglobin harus normal, serta pembuluh darah harus mampu

${ }^{2)}$ Septri. Saat ini Dosen Jurusan Kesehatan dan Rekreasi Fakultas Ilmu Keolahragaan Universitas Negeri Padang 
mengalihkan darah dari jaringan-jaringan yang yang tidak aktif keotot yang sedang aktif yang memutuhkan oksigen lebih besar.

3.) Jantung, paru dengan pembuluh darah yang harus berfungsi dengan baik sehingga oksigen yang di hirup dapat masuk keparu-paru dengan selanjutnya sampai ke daerah lambung. Selama bertahun-tahun telah banyak penelitian yang dilakukan untuk indetifikasi faktor-faktor fisiologi yang menentukan dan membatasi VO2 Max. Meskipun persoalan ini belum tuntas, ada yang beberapa faktor yang mengakibatkan dan menurunnya VO2 Max adalah sebagai berikut:

$$
\mathrm{VO} 2\left(\mathrm{MI} / \mathrm{Kg} / \text { menit }=\frac{\mathrm{VO} 2(\mathrm{LO} 2) \mathrm{X} 1000}{\text { Berat badan }(\mathrm{Kg})} \quad(\text { Pate dkk, 1984) }\right.
$$

Jadi kegemukan badan cendrung mengurangi berat relatif VO2 Max dan kapasitas fungsional dengan menambah berat badan.

4.) Keadaan latihan, kebiasaan latihan dan latar belakang latihan olahragawan dapat mempengaruhi VO2 Max. Kini telah diyakini bahwa fungsi metabolisme otot menyesuaikan diri dengan latihan ketahanan dan meningkatan VO2 Max

5.) Keturunan, meskipun VO2Max dapat ditingkatkan melalui latihan yang sesuai. Kebanyakan penelitian menujukan besarnya peningkatan itu terbatas $10-20 \%$, gambaran ini dapat menganggap rendah peningkatan yang terjadi dalam program jangka panjang waktu latihan intensitas tinggi, dengan demikian jelas bahwa VO2 Max seseorang olahragawan perorangan dapat berbeda- beda karena perbedaan garis keturunan".

\section{Cara-cara Meningkatkan Kesegaran Jasmani}

Dalam upaya peningkatan kesegaran jasmani Saputro dan Suherman dalam Gusril (2004:73) mengatakan: "Untuk mendapatkan kesegaran jasmani dosis latihannya harus mempertahankan tiga faktor, yaitu: 1) intensitas latihan; 2) lama latihan dan; 3) frekuensi latihan. Intensitas latihan kesegaran jasmani

\footnotetext{
${ }^{2)}$ Septri. Saat ini Dosen Jurusan Kesehatan dan Rekreasi Fakultas Ilmu Keolahragaan Universitas Negeri Padang
} 
berkisar antara 72-87 \% dari denyut nadi maksimal (220-umur) disebut "training zone".

Dari pendapat di atas disimpulkan bahwa untuk bisa mendapatkan suatu kesegaran jasmani sangatlah komplit sekali, karena harus melalui beberapa proses latihan yang harus dipertahankan dan dilakukan oleh seseorang itu. Selain komponen yang diuraikan di atas, faktor gizi juga sangat mempunyai peranan penting dalam mendapatkan tingkat kesegaran jasmani yang baik, karena dengan mengkonsumsi makanan yang mengandung gizi yang tinggi sehari-sehari akan dapat merangsang organ tubuh untuk bisa berfungsi secara maksimal dalam melakukan aktivitas sehari-hari.

\section{METODOLOGI}

Penelitian ini tergolong pada penelitian expost facto, menginventaris seluruh situasi yang terjadi berdasarkan atas pengamatan dan kemudian mencari kembali faktor yang diduga menjadi penyebab, melalui pengumpulan data tertentu. Dimana penelitian ini dilakukan untuk mencari perbedaan tingkat kesegaran jasmani siswa-siswi SMK Taruna 2 Padang dengan SMA Pertiwi 1 Padang. Penelitian ini diadakan pada dua tempat yaitu di SMK Taruna 2 Padang dan SMA Pertiwi 1 Padang periode Januari - Februari 2009. Populasi dalam penelitian ini adalah semua siswa SMK Taruna 2 Padang dan SMA Pertiwi 1 Padang kecuali kelas 3 kerna menghadapi ujian nasional. Untuk SMK Taruna 2 Padang berjumlah 55 orang. untuk SMA Pertiwi 1 Padang berjumlah 118 orang

\section{Teknik analisis Data}

Untuk mengolah data, data diolah dengan teknik analisis "t-test". Hal ini sesuai dengan jenis penelitian yang penulis lakukan. Rumus uji " $t$ " menurut (Sudjana, 1992:241) sebagai berikut:

\footnotetext{
${ }^{2)}$ Septri. Saat ini Dosen Jurusan Kesehatan dan Rekreasi Fakultas Ilmu Keolahragaan Universitas Negeri Padang
} 


$$
t=\frac{-\bar{X} 1-X 2}{\sqrt{\left(\frac{s 1^{2}}{n 1}\right)+\left(\frac{s 2^{2}}{n 2}\right)^{2}}}
$$

Keterangan :

$\mathrm{X} 1$ = Mean SMK Taruna 2 Padang

$\mathrm{X} 2=$ Mean SMA Pertiwi 1 Padang

$\mathrm{S}=$ Variasi populasi

$\mathrm{N}=$ Jumlah sampel

\section{HASIL PENELITIAN}

Analisis data dan pembahasan yang dilakukan berkaitan dengan "Perbedaan Tingkat Kesegaran Jasmani Siswa SMK Taruna 2 Padang dan SMA Pertiwi 1 Padang”, juga berdasarkan pada data hasil tes kesegaran jasmani melalui tes kemampuan VO2 Max yang telah penulis dapatkan di lapangan serta diolah dengan teknik statistik uji " $\mathrm{t}$ ” test.

Mengacu pada tujuan dan hipotesis penelitian yang dikemukakan pada penelitian ini, maka analisis data yang dilakukan mencakup pada sub-sub variabel yang penulis teliti.

Perbandingan nilai rata-rata hasil tes kesegaran jasmani siswa SMK Taruna $(33,98)$ dan SMA Pertiwi Padang $(27,27)$ dengan demikian dapat disimpulkan bahwa tingkat kesegaran jasmani siswa SMK Taruna 2 Padang lebih baik dari SMA Pertiwi 1 Padang. Dapat dilihat pada tabel berikut:

\section{Tabel.1}

Kemampuan VO 2 Max Siswa SMK Taruna

\section{Dengan SMA Pertiwi Padang}

\begin{tabular}{|c|c|c|c|c|c|c|}
\hline \multirow[b]{2}{*}{ No. } & \multirow[b]{2}{*}{ Kriteria } & \multicolumn{2}{|c|}{$\begin{array}{l}\text { SMK Taruna } 2 \\
\text { Padang }\end{array}$} & \multicolumn{2}{|c|}{$\begin{array}{l}\text { SMA Pertiwi } \\
1 \text { Padang }\end{array}$} & \multirow[t]{2}{*}{ Keterangan } \\
\hline & & $\mathbf{f}$ & $\%$ & $\mathbf{f}$ & $\%$ & \\
\hline 1 & Tinggi & 0 & 0 & 0 & 0 & \\
\hline
\end{tabular}

${ }^{2)}$ Septri. Saat ini Dosen Jurusan Kesehatan dan Rekreasi Fakultas Ilmu Keolahragaan Universitas Negeri Padang 


\begin{tabular}{|l|l|l|l|l|l|l|}
2 & Bagus & 0 & 0 & 0 & 0 & \\
\hline 3 & Cukup & 2 & 14 & 0 & 0 & \\
\hline 4 & Sedang & 3 & 21 & 1 & 7 & \\
\hline 5 & Kurang & 5 & 36 & 6 & 43 & \\
\hline 6 & Rendah & 4 & 29 & 7 & 50 & \\
\hline Jumlah & 14 & 100 & 14 & 100 & \\
\hline
\end{tabular}

Hasil pengambilan data tingkat kesegaran jasmani terhadap 14 orang siswa SMK Taruna 2 Padang didapat hasil responden dengan tingkat kategori cukup (14\%) 2 orang, sedang (21\%) 3 orang, kurang (36\%) 5 orang, dan responden kategori rendah $(29 \%) 4$ orang.

Hasil pengambilan data tingkat kesegaran jasmani terhadap 14 orang siswa SMA Pertiwi 1 Padang didapat hasil tingkat kategori sedang (7\%) atau 1 orang, kurang (43\%) atau 6 orang, dan kategori rendah (50\%) atau 7 orang. Untuk lebih jelasnya dapat dapat dilihat pada grafik dibawah ini:

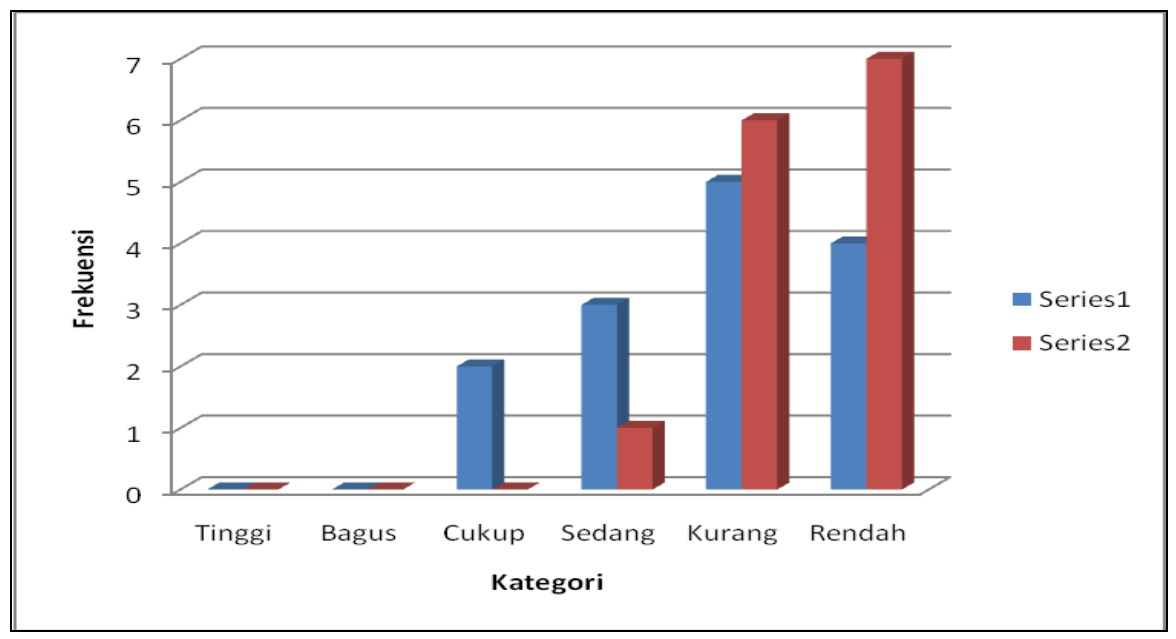

Gambar 1. Grafik Distribusi Frekuensi VO 2 Max Siswa SMK Taruna 2 Padang dengan SMA Pertiwi 1 Padang

\section{Uji Hipotesis}

Untuk menguji apakah hipotesis yang diajukan dalam penelitian ini diterima atau tidak, maka dilakukan pengujian data dengan menggunakan uji " $\mathrm{t}$ " test. Hipotesis ini dapat dikemukakan sebagai berikut: "terdapat perbedaaan tingkat kesegaran jasmani siswa SMK Taruna 2 Padang dengan SMA Pertiwi 1 Padang".

${ }^{2)}$ Septri. Saat ini Dosen Jurusan Kesehatan dan Rekreasi Fakultas Ilmu Keolahragaan Universitas Negeri Padang 
Berikut disajikan hasil pengolahan data perbandingan tingkat kesegaran jasmani siswa SMK Taruna 2 Padang dengan Siswa SMA Pertiwi 1 Padang. Untuk lebih jelasnya dapat dilihat pada tabel berikut ini:

Tabel. 2

Distribusi Rata-rata Tingkat Kesegaran Jasmani Siswa SMK Taruna 2 Padang dan SMA Pertiwi 1 Padang

\begin{tabular}{|l|l|l|l|l|l|}
\hline Variabel & Mean & SD & SE & p Value & N \\
\hline $\begin{array}{l}\text { Tingkat Kesegaran } \\
\text { Jasmani }\end{array}$ & & & & & \\
\hline SMK Taruna 2 Padang & 33,98 & 6,71 & 1,79 & 0,001 & \\
\hline SMA Pertiwi 1 Padang & 27,27 & 3,69 & 0,99 & & 14 \\
\hline
\end{tabular}

Rata-rata kemampuan VO2 Max atau tingkat kesegaran jasmani siswa

SMK Taruna 2 Padang adalah 33,98 dengan standar deviasi 6,71. Rata-rata tingkat kesegaran jasmani siswa SMA Pertiwi 1 Padang adalah 27,27 dengan standar deviasi 3,69. Hasil uji statistik didapatkan nilai $\mathrm{p}=0,001$ maka dapat disimpulkan ada perbedaan tingkat kesegaran jasmani antara siswa SMK Taruna 2 Padang dengan SMA Pertiwi 1 Padang. Untuk lebih jelasnya dapat dilihat pada tabel uji " $t$ " berikut ini:

Tabel. 3

Distribusi Rata-rata Tingkat Kesegaran Jasmani

Siswa SMK Taruna dan SMA Pertiwi Padang

\begin{tabular}{|l|l|l|l|l|l|}
\cline { 1 - 1 } Variabel & Mean & SD & SE & t & p \\
\hline Tingkat Kesegaran Jasmani & & & & & \\
\cline { 1 - 1 } SMK Taruna Padang & $-6,71$ & 6,14 & 1,64 & $-4,09$ & 0,001 \\
\cline { 1 - 1 } SMA Pertiwi Padang & & & & & \\
\hline
\end{tabular}

Dari hasil perhitungan " $\mathrm{t}$ " test di atas terlihat bahwa nilai $\mathrm{t}_{\text {hitung }}=-4,09<\mathrm{t}$ tabel $=$ 1,76 pada taraf signifikan $\alpha=0,001$ hal itu berarti bahwa $H_{0}$ diterima dan $H_{i}$ ditolak, dengan demikian hipotesis yang menyatakan terdapat perbedaan tingkat kesegaran jasmani antara siswa SMK Taruna 2 Padang dengan SMA Pertiwi 1 Padang dapat diterima. Hal ini juga ditujukan dengan tingkat signifikan sebesar $0,001<0,05$, yang berarti menunjukan hasil bahwa terdapat perbedaan yang

${ }^{2)}$ Septri. Saat ini Dosen Jurusan Kesehatan dan Rekreasi Fakultas Ilmu Keolahragaan Universitas Negeri Padang 
signifikan antara tingkat kesegaran jasmani antara siswa SMK Taruna 2 Padang dengan tingkat kesegaran jasmani siswa SMA Pertiwi 1 Padang.

\section{PEMBAHASAN}

Berdasarkan hasil pengujian hipotesis dapat diambil kesimpulan bahwa hipotesis yang diajukan pada penelitian ini dapat diterima dengan gambaran hasil hipotesis yang ada setelah penelitian.

Secara keseluruhan hasil terhadap 14 orang siswa SMK Taruna Padang guna untuk mengetahui kemampuan VO 2 Max atau tingkat kesegaran jasmani yang diukur melalui Bleep Test, diketahui data tertinggi yang diperoleh adalah 45,20 dan data terendah adalah 25,00, rata-rata (mean) 33,98, standar deviasi 6,71, modus 25,00 dan median 32,85. Didapat hasil responden dengan tingkat kesegaran jasmani kategori cukup (14\%) 2 orang, sedang (21\%) 3 orang, kurang (36\%) 5 orang, dan responden kategori rendah (29\%) 4 orang.

Hasil terhadap 14 orang siswa SMA Pertiwi 1 Padang guna untuk mengetahui kemampuan VO 2 Max atau tingkat kesegaran jasmani yang diukur melalui Bleep Test, diketahui data tertinggi yang diperoleh adalah 33,20 dan data terendah adalah 21,40, rata-rata (mean) 27,27, standar deviasi 3,69, modus 27,90 dan median 27,90. Hasil pengambilan data tingkat kesegaran jasmani terhadap 14 orang siswa SMA Pertiwi 1 Padang didapat hasil tingkat kategori sedang (7\%) atau 1 orang, kurang (43\%) atau 6 orang, dan kategori rendah (50\%) atau 7 orang

Berdasarkan hasil hipotesis, maka rincian pembahasan hasil penelitian dapat simpulkan sebagai berikut: Terdapat perbedaan tingkat kesegaran jasmani antara siswa SMK Taruna 2 Padang dengan siswa SMA Pertiwi 1 Padang yang ditunjukan dengan skor $X_{1}=33,98>X_{2}=27,27$ dan dengan menggunakan $t$ test didapatkan $\mathrm{t}_{\text {hitung }}=-4,09<\mathrm{t}_{\text {tabel }} 1,76$.

\section{KESIMPULAN}

Berdasarkan hasil temuan pengujian hipotesis dapat diungkap bahwa hipotesis yang diajukan pada penelitian ini dapat diterima.

${ }^{2)}$ Septri. Saat ini Dosen Jurusan Kesehatan dan Rekreasi Fakultas Ilmu Keolahragaan Universitas Negeri Padang 
1. Dari hasil analisis data dapat disimpulkan bahwa 9 orang siswa putra SMK Taruna 2 Padang memperoleh tingkat kesegaran jasmani dengan kategori sedang (33\%) atau 3 orang dan SMA Pertiwi 1 Padang tingkat kesegaran jasmani dari 5 orang adalah kategori rendah (80\%) atau 4 orang. Dan siswi putri SMK Taruna 2 Padang dari 5 orang diperoleh hasil responden dengan tingkat kesegaran jasmani adalah kategori kurang (60\%) atau 3 orang dan siswi putri SMA Pertiwi 1 Padang dari 9 orang siswi diperoleh hasil tingkat kategori kurang (56\%) atau 5 orang.

2. Terdapat perbedaan tingkat kesegaran jasmani antara siswa SMK Taruna 2 Padang dengan siswa SMA Pertiwi 1 Padang yang ditunjukan dengan skor $\mathrm{X}_{1}=33,98>\mathrm{X}_{2}=27,27$ dan dengan menggunakan $\mathrm{t}$ test didapatkan $t_{\text {hitung }}=-4,09>t_{\text {tabel }} 1,76$. Dengan demikian tingkat kesegaran jasmani siswa SMK Taruna 2 Padang lebih baik dibandingkan dengan tingkat kesegaran jasmani SMA Pertiwi 1 Padang.

\section{Saran}

Berdasarkan kesimpulan penelitian diatas maka penulisan menyarankan beberapa hal:

1. Kepada pihak Dinas Pendidikan Kota Padang untuk mengadakan pertandingan Olahraga secara priodik.

2. Kepada Kepala Sekolah dan Guru Olahraga SMA Pertiwi, agar mendorong siswanya untuk melakukan kegiatan olahraga di luar jam pelajaran penjas orkes di sekolah.

3. Kepada pihak sekolah untuk melengkapi sarana dan prasarana penunjang mata pelajaran penjas orkes di sekolah

4. Kepada para peneliti lain diharapkan dapat mengembangkan penelitian ini dengan jumlah sampel yang lebih banyak lagi atau dengan variabel-variabel lain yang belum diteliti sehingga faktorfaktor yang mempengaruhi tingkat kesegaran jasmani siswa dapat diketahui.

2) Septri. Saat ini Dosen Jurusan Kesehatan dan Rekreasi Fakultas Ilmu Keolahragaan Universitas Negeri Padang 


\section{REFERENSI}

Arikunto, Suharsimi. (1992). Manajemen Penelitian. Jakarta : Depdikbud

Cooper \& Brown. (1990). Aerobik. Jakarta : PT. Gramedia

GBHN. (1994-2004). UU Nomor 20 Tahun 2003 Tentang Sistem Pendidikan Nasional. Jakarta.

Depdikbud. (2006). Pusat Kesegaran Jasmani dan Rekreasi. Jakarta: Depdikbud.

Depdiknas.(2003). Tes Kesegaran Jasmani Indonesia. Jakarta: Pusat

Pengembangan Kualitas Sumber Daya Manusia.

Efwilza. (2002). Perbedaan Tingkat Kesegaran Jasmani Murid SD No. 16 dikawasan Pertambangan Batu Bara Ombilin dengan Murid SDN 12 Luar Kawasan Batau Bara Ombilin Kota Sawah Lunto. Padang : FIK UNP

Gusril. (2004). Perkembangan Motorik Pada Masa Anak-anak. Dirjen Olahraga Depertemen Pendidikan Nasional

Gusril. (1991). Kesegaran Jasmani Untuk Manula (Materi Kuliah) Pendidikan Kesehatan Rekreasi. FPOK IKP Padang

Hairy, Junusul dan Muchktar Ahadi. (1989). Kesegaran Jasmani. Padang :FPOK IKIP Padang

Ichsan, M. (1998). Pendidikan Kesehatan dan Olahraga. Bandung : Percetakan Advent Indonesia

Ismana Joni. (2007) Studi Tentang Tingkat VO2 Max Siswa SMK Negeri 3 Padang. FIK: UNP

Kosbian. (2004). Pendidikan Kesegaran Jasmani. Jakarta: PT. Gramedia

Mulyasa. (2006). Kurikulum Tingkat Satuan Pendidikan. Remaja Rosda Karya.

Narbuko, Kholid dkk.(2003) Metodologi Penelitian. Jakarta : Bumi Aksara

O Sullivan, Susane. (1987). Fully Fit 60 Minute A Week. New York: Thorsons Publising Group.

Sardjono, Anas. (1989). Pengatur Statistik Pendidikan. Jakarta: CV Rajawali

Sadoso. (2003). Pendidikan Kesehatan Jamani. Jakarta: Depdikbud

Siregar. (1994). Kesegaran Jasmani. Jakarta : Rineka Cipta

${ }^{2)}$ Septri. Saat ini Dosen Jurusan Kesehatan dan Rekreasi Fakultas Ilmu Keolahragaan Universitas Negeri Padang 
Sudjana. (1992) Metode Statistik. Bandung : Tarsito

Sudjana. (2002). Pembinaan dan Pengembangan Kurikulum Di Sekolah. Bandung : Sinar Baru Algesindo.

Sumarharjono. (1984). Pengertian Tentang Kesegaran Jasmani dan Tes Kardiorespirasi. Jakarta : Pusat Ilmiah Keolahragaan

UNP (2007). Buku Panduan Penulisan Tugas Akhir/Skripsi UNP. Padang: FIK UNP

${ }^{2)}$ Septri. Saat ini Dosen Jurusan Kesehatan dan Rekreasi Fakultas Ilmu Keolahragaan Universitas Negeri Padang 